\title{
An antibody against stored blood associated with cirrhosis of the liver and false-positive serological tests for syphilis
}

\author{
J. A. EASTON, C. J. PRIEST, AND CAROLYN M. GILES \\ From the Department of Haematology, Louis Jenner Laboratory, St. Thomas's Hospital and \\ Medical School, London, and the M.R.C. Blood Group Reference Laboratory, London
}

SYNOPSIS A case of cirrhosis of the liver, associated with false-positive serological tests for syphilis and an antibody active against stored red cells, is presented. Methods used in the identification of the 'stored red cell' antibody are described.

Antibodies against stored as opposed to fresh blood have previously been reported (Stratton, Renton, and Rawlinson, 1960; Jenkins and Marsh, 1961). In the three cases reported by Jenkins and Marsh haemolytic anaemia and positive serological tests for syphilis were associated with this antibody. In the case presented here there was no evidence of gross haemolytic anaemia, but cirrhosis of the liver and positive serological tests for syphilis were found.

\section{CASE HISTORY}

The patient, a woman aged 60 years, was first seen in May 1964. She complained of tiredness and intermittent swelling of the ankles for the previous year. Apart from thyroidectomy for thyrotoxicosis in 1948 , she had had no serious illness.

On examination, she was found to have an enlarged liver and an enlarged spleen together with multiple spider naevi. Her haemoglobin was 13.6 g. per $100 \mathrm{ml}$.; white cell counts ranged from 3,600 per c.mm. to 4,800 per c.mm. with normal differential counts. Platelets numbered 130,000 per c.mm. and the erythrocyte sedimentation rate (Westergren) was $87 \mathrm{~mm}$. in one hour. Reticulocytes were slightly increased at $3.6 \%$ of red cells and the $\mathrm{T}_{2}{ }^{51} \mathrm{Cr}$ was 21 days. Serum urea, electrolytes and plasma cholesterol were all normal. The total plasma protein concentration was $8.1 \mathrm{~g}$. per $100 \mathrm{ml}$., albumin 3.7 g. per $100 \mathrm{ml}$, and globulin $4.4 \mathrm{~g}$. per $100 \mathrm{ml}$.; electrophoresis of serum proteins showed a moderate increase in $\gamma$ globulin. Lupus erythematosus cell preparations and the anti-nuclear factor test were negative. $I^{131}$ tests showed the patient to be euthyroid. Tests for faecal occult blood were positive on three occasions.

Liver biopsy showed portal fibrosis and there was portal hypertension (splenic pulp pressure of $31 \mathrm{~cm}$. of water). Extensive venous collaterals in the upper abdomen as well as oesophageal and gastric varices were demon strated.

SEROLOGY

A blood sample was taken for grouping and crossmatching. The cells were group A Rh-positive. The serumo reacted with ficin-treated group $O \mathbf{R}_{1} \mathbf{R}_{\mathbf{2}}$ control cellső causing haemolysis. Further investigation indicated that a strong cold auto-antibody of wide thermal amplitude was present, capable of causing haemolysis at $37^{\circ} \mathrm{C}$. of ficin-treated cells in the presence of complement.

In order to determine the specificity of the antibody more detailed serological study was undertaken. The patient's cells had to be washed in warm saline $\left(37^{\circ} \mathrm{C}\right.$. . to prevent auto-agglutination at temperatures below? $37^{\circ} \mathrm{C}$. The cells were grouped as $\mathrm{A}_{1}, \mathrm{CDe} / \mathrm{cde}, \mathrm{N}, \mathrm{S}+\mathrm{3}$ $\mathrm{P}_{1}-, \mathrm{Lu}^{\mathrm{a}}-, \mathrm{K}-, \mathrm{Le}^{\mathrm{a}}-, \mathrm{Fy}^{\mathrm{a}}-$. A strong positive direct: anti-human globulin reaction was demonstrated witho the patient's cells using an anti-non-gamma reagent, but only a very weak reaction was obtained with an anti-o gamma reagent. Neither of the reactions was inhibited by the addition of purified gamma globulin to the antio human globulin reagents.

Serum which was separated from the patient's redo cells at $37^{\circ} \mathrm{C}$. gave optimum reactions. All adult group $\mathrm{O}$ and $\mathrm{A}$ cell samples, including the patient's own and one foetal group A cell sample, reacted strongly at roomw temperature and at $4^{\circ} \mathrm{C}$. in saline and albumin. Similarlye all ficin-treated cells reacted at $37^{\circ} \mathrm{C}$. after heat inactivaco tion of the serum at $56^{\circ} \mathrm{C}$. It is thought that these re actions were rouleaux formation which masked true? agglutination. The raised gamma-globulin level and higho erythrocyte sedimentation rate would support this in terpretation.

Two techniques were found to demonstrate the pre $\frac{\rho}{8}$ sence of the antibody particularly well. In the firso technique fresh serum containing complement was tested at $37^{\circ} \mathrm{C}$ against ficin-treated cells which showed varying 
degrees of haemolysis. In the second, the serum was inactivated with the disodium salt of ethylene-diaminetetracetic acid (E.D.T.A.) and used to sensitize the cells which were then incubated with human complement in a two-stage sensitization for the antihuman globulin technique (Polley and Mollison, 1961). Positive antiglobulin results were obtained which followed the same pattern as the haemolysis.

Fresh cell samples were not haemolysed and did not react by the two-stage anti-globulin technique, whereas glycerol-stored cells, acid-citrate dextrose stored cells, and cells heated to $56^{\circ} \mathrm{C}$. for 30 minutes reacted well by both techniques.

Titration of heat-inactivated serum against ficin-treated cells showed that the stored cells reacted better than the fresh cells, the titres ranging between 8 and 64 according to the age of each sample.

No specificity could be demonstrated by the use of adult $\mathrm{i}$, Bombay $\mathrm{O}_{h}$ and $\mathrm{P}$-negative $(\mathrm{Pk})$ cell samples. In fact these rare cell types reacted strongly since they had been stored in glycerol.

The antibody was shown to be directed towards an antigen not present on normal fresh red cells, but universally present in varying degrees on stored red cells. We were not able to show whether the patient's own cells were haemolysed by her fresh serum but the positive direct antiglobulin reaction suggests that her own cells may have had the 'stored-cell' antigen developed to a slight degree and consequently had become sensitized.

Routine tests for syphilis, including the Wassermann reaction, Reiter's protein complement-fixation test, and Price's precipitation reactions, were all positive, although negative Treponema pallidum immobilization and fluorescent treponema antibody tests suggested that these positive tests were almost certainly non-specific. The Venereal Diseases Reference Laboratory (V.D.R.L.) slide test was also positive to a serum dilution of $1 / 32$. Two separate antibodies were demonstrated in the patient's serum, the Wassermann reaction remaining positive after complete absorption of the stored red cell antibody by appropriate red cells. Other antibody tests were inconclusive. Precipitin thyroid antibodies were negative, the tanned red cell thyroid antibody test was positive at only $1 / 250$ serum dilution, and the thyroid complementfixation test was negative. The Rose-Waaler differential agglutination titre was positive to $1: 2$ only, and the latex fixation test was negative. The Donath Landsteiner test was negative.

\section{DISCUSSION}

The association of biological false positive serological tests for syphilis and an antibody against stored blood in the same patient is rare. In the cases reported by Jenkins and Marsh (1961), haemolytic anaemia was also found. In the present case, although the direct antiglobulin test was positive, the ${ }^{51} \mathrm{Cr}$ half-life was only slightly less than normal, and there was no previous history of haemolytic anaemia. The reticulocyte count was raised but bleeding from varices could very well account for this finding, as tests for faecal occult blood were positive. The patient was not jaundiced, and all the evidence indicated that haemolysis, if occurring at all, was minimal.

Since the Treponema pallidum immobilization test and the fluorescent treponema antibody test were negative, the other positive tests for syphilis in the present case were almost certainly biological false positives. Biological false-positive tests for syphilis are found in association with many conditions, including certain infections, some collagen diseases, and in occasional patients with acquired haemolytic anaemia. Selenkow, Cline, Fudenberg, and Brooke (1961) describe a case of chronic lymphoid thyroiditis associated with biological false-positive tests for syphilis. As in the present case the serum gamma globulin level was raised. In their case selective absorption of antibodies showed that the Wassermann antibody was not the same as the thyroid antibody.

As Jenkins and Marsh (1961) point out, if fresh 'non-ficinised' cells are used for antibody detection stored red cell antibodies may be missed. On the other hand in the cases reported so far it was noted that the patient's cells gave a positive direct antiglobulin reaction which should draw attention to the presence of an atypical antibody. The stored red cell antibody has been reported to disappear on treatment with steroids (Jenkins and Marsh, 1961). In the present case, there was no indication for such treatment. The presence of this antibody against stored red cells would lead to considerable difficulty in the routine cross-matching of blood, and if the patient required transfusion it would be necessary to use fresh blood.

We should like to thank Dr. B. Creamer for permission to publish this case.

REFERENCES

Jenkins, W. J., and Marsh, W. L. (1961). Lancet, 2, 16.

Polley, Margaret, J., and Mollison, P. L. (1961). Transfusion (Philad.), 1,9 .

Selenkow, H. A., Cline, M. J., Fudenberg, H., and Brooke, M. S. (1961). Amer.J. Med., 31, 144.

Stratton, F., Renton, P. H., and Rawlinson, V. I. (1960). Lancet, 1, 1388 . 